A PHENOMENOLOGICAL RELATIONSHIP FOR PREDICTING THE SURFACE AREAS OF THERMAL PLUMES IN LAKES

\author{
J. G. Asbury and A. A. Frigo
}

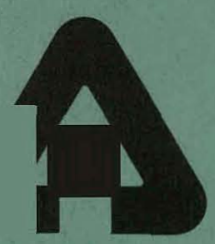




\section{DISCLAIMER}

This report was prepared as an account of work sponsored by an agency of the United States Government. Neither the United States Government nor any agency Thereof, nor any of their employees, makes any warranty, express or implied, or assumes any legal liability or responsibility for the accuracy, completeness, or usefulness of any information, apparatus, product, or process disclosed, or represents that its use would not infringe privately owned rights. Reference herein to any specific commercial product, process, or service by trade name, trademark, manufacturer, or otherwise does not necessarily constitute or imply its endorsement, recommendation, or favoring by the United States Government or any agency thereof. The views and opinions of authors expressed herein do not necessarily state or reflect those of the United States Government or any agency thereof. 


\section{DISCLAIMER}

Portions of this document may be illegible in electronic image products. Images are produced from the best available original document. 
The facilities of Argonne National Laboratory are owned by the United States Government. Under the terms of a contract (W-31-109-Eng-38) between the U. S. Atomic Energy Commission, Argonne Universities Association and The University of Chicago, the University employs the staff and operates the Laboratory in accordance with policies and programs formulated, approved and reviewed by the Association.

\section{MEMBERS OF ARGONNE UNIVERSITIES ASSOCIATION}

The University of Arizona Carnegie-Mellon University Case Western Reserve University The University of Chicago University of Cincinnati Illinois Institute of Technology University of Illinois Indiana University Iowa State University The University of Iowa
Kansas State University The University of Kansas Loyola University Marquette University Michigan State University The University of Michigan University of Minnesota University of Missouri Nurthwestern University University of Notre Dame
The Ohio State University Ohio University

The Pennsylvania State University

Purdue University

Saint Louis University

Southern Illinois University

The University of Texas at Austin

Washington University

Wayne State University

The University of Wisconsin

\section{NOTICE}

This report was prepared as an account of work sponsored by the United States Government. Neither the United States nor the United States Atomic Energy Commission, nor any of their employees, nor any of their contractors, subcontractors, or their employees, makes any warranty, express or implied, or assumes any legal liability or responsibility for the accuracy, completeness or usefulness of any information, apparatus, product or process disclosed, or represents that its use would not infringe privately-owned rights.

Printed in the United States of America

$$
\text { Available from }
$$

National Technical Information Service

U.S. Department of Commerce

5285 Port Royal Road

Springfield, Virginia 22151

Price: Printed Copy $\$ 3.00$; Microfiche $\$ 0.95$ 
ANL/ES- 5

ARGONNE NATIONAL LABORATORY

9700 South Cass Avenue

Argonne, Illinois 60439

\section{A PHENOMENOLOGICAL RELATIONSHIP FOR PREDICTING THE SURFACE AREAS OF THERMAL PLUMES IN LAKES}

by

J. G. Asbury and A. A. Frigo

Center for Environmental Studies

This report was prepared as an account of work sponsored by the United States Government. Neither the United States nor the United States Atomic Energy Commission, nor any of their employees, nor any of their contractors, subcontractors, or their employees, makes any warranty, express or implied, or assumes any. legal liability or responsibility for the accuracy, completeness or usefulness of any information, apparatus, product or process disclosed, or represents that its use would not infringe privately owned rights. 


\section{THIS PAGE \\ WAS INTENTIONALLY \\ LEFT BLANK}


TABLE OF CONTENTS

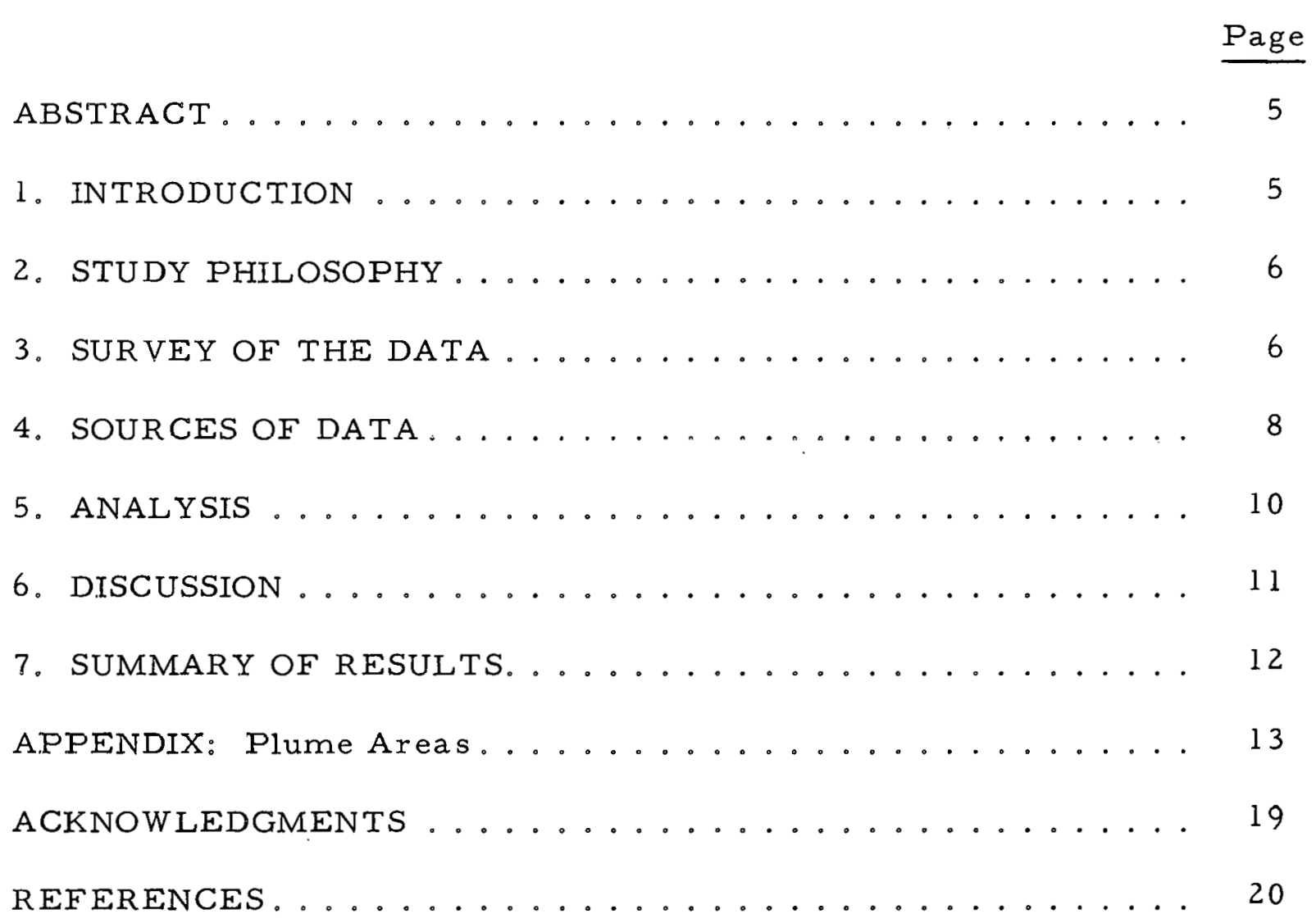


THIS PAGE

WAS INTENTIONALLY

LEFT BLANK 


\title{
A PHENOMENOLOGICAL RELATIONSHIP \\ FOR PREDICTING THE SURFACE AREAS \\ OF THERMAL PLUMES IN LAKES
}

by

J. G. Asbury and A. A. Frigo

\begin{abstract}
A phenomenological relationship for surface areas within isotherms has been developed for thermal plumes in large lakes. The relationship, based upon the field data of other investigators, represents a useful rule of thumb for predicting surface areas of buoyant thermal plumes.
\end{abstract}

\section{INTRODUCTION}

The problem of predicting the dispersive behavior of heated effluents in natural water bodies has received the attention of many investigators in recent years. From a practical point of view, a certain degree of success has been achieved with regard to describing the certain types of discharges. For example, the behavior of heated effluents in uniform river-type crossflows, can be reasonably well predicted. That this has been achieved without the emergence of a universally accepted theory of plume dynamics indicates the large role phenomenology currently plays in plume analysis.

The state of the art for predicting lake plumes is less satisfactory, even from a phenomenological point of view. Although the dynamics governing the zone of flow establishment are presumably the same for lake and river discharges, the dynamics in the region of established flow are quite different. The lake situation is considerably more complicated, due to much larger dynamic variations in the structure of the receiving body of water. Variations in the direction and magnitude of near-shore currents and in the ambient diffusivity greatly complicate the problem of modeling the dispersive processes.

One of the simplest methods of parameterizing plume dispersion is in terms of surface areas within isotherms. In the present study we have adopted a completely phenomenological approach in attempting to find a relationship that could be used to predict plume surface areas. The approach was based upon two considerations: 1) The behavior of lake plumes beyond the zone of flow establishment is governed by lake processes for which adequate models do not exist, and 2) there does exist a published set of lake-plume temperature measurements which can be examined for relationships among the plume variables. 


\section{STUDY PHILOSOPHY}

Edinger and Polk, in an analysis of thermal-plume dispersion, derived a functional relationship for plume surface areas contained within excess temperature contours. ${ }^{1}$ The authors as sumed Fickian-type diffusion and considered conservative and nonconservative two-dimensional dispersion and conservative three-dimensional dispersion. For the simplest case--conservative, two-dimensional dispersion--they found a relationship of the form $A / A_{n}=f\left(\theta / \theta_{0}\right)$, where $f\left(\theta / \theta_{0}\right)$ is a function of the fractional excess temperature $\theta / \theta_{0}$, and $A / A_{n}$ is the nondimensional plume area contained within the isotherm at excess temperature $\theta$. For a two-dimensional, conservative plume, the scaling area $A_{n}$ was found equal to $4 / \pi^{3 / 2} \cdot Q^{3} / \mathrm{Du}^{2} \mathrm{~d}^{3}$, where $Q$ is the volumetric discharge flow rate, $D$ is the ambient diffusivity, $\mathrm{u}$ is the ambient velocity, and $\mathrm{d}$ is the plume depth, assumed constant. After numerically integrating $f\left(\theta / \theta_{0}\right)$, the authors graphed the relationship $\theta / \theta_{0}$ versus $A / A_{n}$ on log-log paper.

Perhaps more important than giving exact analytical solutions, the work of Edinger and Polk provides an elegant method of data display which can be used to group and compare data. In particular, it suggested to us that an empirical relation for plume spreading might be discovered by reducing existing field data and presenting it on plots of $\theta / \theta_{0}$ versus $A / A_{n}$. The parameterization of $A_{n}$ could be adjusted to provide the best agreement among existing lake plume data. Such an empirical, "plume-area" approach would greatly simplify some of the problems normally encounterer in developing predictive formulas for thermal plumes and at the same time would consider one of the most important features of the thermal plume, namely, the areal extent of its surface water.

The parameterization of $A_{n}$ will be limited by the type, quality, and quantity of the existing lake plume data. The data are discussed in the next two sections.

\section{SURVEY OF THE DATA}

We identified scven useful sets of published lake plume data during the course of a literature survey. The sources of data are listed in Table I.

TART, E. I. Lake Plume Data

\begin{tabular}{lcc}
\hline \multicolumn{1}{c}{ Site } & $\begin{array}{c}\text { Number } \\
\text { uf Plumes } \\
\text { Analyzed }\end{array}$ & Source \\
\hline Waukegan, Lake Michigan & 5 & Ref. 2 \\
Big Rock, Lake Michigan & 1 & Ref. 3 \\
Milliken, Cayuga Lake & 3 & Ref. 4 \\
Waukegan, Lake Michigan & 1 & Ref. 5 \\
Michigan City, Lake Michigan & 2 & Ref. 5 \\
Allen S. King, Lake St. Croix & 9 & Ref. 6 \\
Douglas Point, Lake Huron & 2 & Ref. 7 \\
\hline
\end{tabular}


With one exception, Table I lists all the lake plume data which we could identify and which we judged to be useful for the type of analysis out lined in Section 2. The one exception is the rather extensive temperature data collected at Waukegan by Biotest Laboratories under contract with Commonwealth Edison Company. The sole reason for not including the Biotest data, which were readily available to us, was our inclination to not overly emphasize the Waukegan site in the analysis.

Several sources of data are not included in Table I because they failed to satisfy the "usefulness" criteria eventually imposed on the data base. (See below.) There are doubtless other sources of published data, which would have satisfied these criteria, but which simply did not come to our attention.

The type and quality of the plume data referenced in Table I vary considerably; however, a few generalizations about the data are possible. (The individual measurements are summarized more carefully in Section 4.)

A "typical" plume measurement consisted of temperature readings collected over a preestablished spatial grid. Additional data usually included intake and outfall temperatures as well as the volumetric discharge flow rate. Where discharge flow rates were not reported, we were able to obtain these through personal communication, either with the investigator or with the utility personnel.

Ambient-current measurements were not always performed and reported. In general, the paucity of current data prevented a more extensive analysis and comparison of data from the various sites.

Constant-temperature contours (isotherms) were usually constructed from the raw data by the investigators. The isotherm plots presented the opportunity for determining plume area within isotherms. Most of the studies listed in Table I included temperature measurements at several depths. There is, however, the problem of assigning a unique value to plume depth which is characteristic of a given plume. For this reason, a comparison of plumes on the basis of depth is very difficult.

Two conclusions can be drawn from a survey of the data:

(1) The analysis is limited, essentially, by the quality of the weakest data sets. The scaling area, $A_{n}$, can be easily related only to the volumetric discharge flow rate. Lack of data or the difficulty of assigning plume-wide values to other variables prevents the parameterization of $A_{n}$ in terms of other variables such as ambient velocity, ambient diffusivity, and plume depth. The most straightforward parameterization of $A_{n}$, therefore, is of the form $A_{n}=Q^{a}$, where the exponent a is to be determined. 
(2) Not all the data of Refs. 2-7 are "useful" for the kind of analysis outlined in Section 2. The plume measurements from any given report are not of equal quality. Temperature data for some plumes are very sparse. In other cases, a strong temperature gradient, usually due to upwelling, makes it impossible to assign a unique value to the temperature of the ambient lake water. We therefore found it necessary to establish a set of criteria, which could be used to define an acceptable ("useful ") plume measurement. An acceptable measurement included:

(a) Sufficient temperature data to permit the drawing of at least three closed isotherms.

(b) Measurements of the intake and outfall temperatures.

(c) Measurement of the volumetric discharge flow rate.

(d) Measurement of the ambient lake temperature, with no indication of large thermal gradients in the ambient lake water.

\section{SOURCES OF DATA}

Plume data from six publications were used. The data were collected at six different sites. (At Waukegan, data were gathered by two authors.) The following is a brief description of the individual measurements. Numerical values of plume variables which were used in the analyses are given in the appendix. For more complete descriptions of the individual measurements, see the original publications.

(1) Romberget al. ${ }^{2}$ conducted 17 surveys of thermal plumes near the outfall of Commonwealth Edison's fossil-fuel powcr plant at Waukegan, Illinois, during the summer of 1970. Data collected included surface and subsurface temperatures in the plume, as well as in the ambient lake and in the discharge canal. Plant operating data, incluting generating loud and discharge flow rate, were reported for each survey. Meteorological data and current data were collected during most of the measurements. Diffusivities were not measured. The investigators constructed constant. temperature contours for 16 of the surveys.

We took areas within isotherms directly from Ref. 2. Of the 16 plumes, only five satisfied the "usefulness" criteria of Section 3. Eight plumes were rejected due to the presence of upwelling, which made it impossible to assign a unique value to the ambient lake temperature.

(2) As part of a study of biological effects of heated discharges, Krezoski ${ }^{3}$ surveyed the plume at Consumer Power Company's Big Rock Point Nuclear Plant near Charlevoix, Michigan. Isotherms were drawn 
for the plume measured on June 18, 1968. We obtained the discharge flow rate through personal communication with Mr. C. Axtell of Consumer Power Company.

(3) Sundaram et al. ${ }^{4}$ conducted an extensive investigation. of the physical effects of thermal discharges on Cayuga Lake. This work included a study of the thermal plume from the Milliken Generating Station. Six isotherm maps, which were developed from infrared overflight data, are presented in Ref. 4. We did not examine three of these plumes because they did not include at least three closed isotherms. The discharge flow rates were furnished to us by Mr.S. A. Lyon of New York State Electric and Gas Corporation.

Reference 4 contains considerable plume, lake, and meteorological data which were not used in the present study.

(4) Ayers et al. ${ }^{5}$ surveyed plumes at the Michigan City Generating Station on June 26 and 28, 1969, and at the Waukegan Generating Station on June 30, 1969. These surveys were made in support of biochemical investigations in the vicinity of the two outfalls. Subsurface as well as surface temperature contours were developed for two of the three surveys. We used the areas within surface isotherms from all three surveys.

Intake and outfall temperatures were reported by Ayers et al. for all three plumes.

(5) Fitch $^{6}$ conducted 10 temperature surveys in Lake St. Croix near Northern States Power Company's Allen S. King Generating Plant. The measurements, performed during the summers of 1969 and 1970, were made using the Minnesota State coordinate grid system.

Intake, outfall, and ambient lake temperatures were measured at the beginning and end of eacli survey.

We obtained details concerning the measurement technique and the presentation of the data through personal communication with Mr.D. Bohn and Mr. J.Bechthold of Northern States Power Company. We learned that some of the temperature data were corrected in order to account for observed changes in the ambient water temperature during the measurements. This change in ambient water temperature no.doubt also. accounts for the difference between outfall temperatures which were reported for the beginnings and ends of some of the surveys. To eliminate this ambiguity, we set the discharge temperature $T_{D}$ equal to $T_{200}+1^{\circ} \mathrm{F}$, where $T_{200}$, the temperature of the plume water $200 \mathrm{ft}$ from the outfall along the plume axis, was determined from the isotherm plots. This simple algorithm for outfall tempcrature is based upon the nhserved rates of temperature decay in the near-field region of the Allen $\mathrm{S}$. King. Plant and should be accurate to $\pm 0.5^{\circ} \mathrm{F}$. 
Using a planimeter, we measured areas:within isotherms for the nine isotherm plots that satisfied the criteria given in Section 3 . Areas for the three surveys conducted during 1969 were measured from large engineering drawings supplied by Northern States Power Company.

(6) Csanady et al. ${ }^{7}$ performed rather detailed measurements of several shore-parallel plumes at the Douglas Point Nuclear Power Plant on Lake Huron during August 1970. Sufficient vertical temperature data and current data were collected during these studies so that the authors were able to determine plume heat fluxes across yertical transects.

Of the four horizontal isotherm plots presented in Ref. 7, two (those for August 24 and 25) include three or more closed isotherms. Although these isotherms refer to a depth of $1.5 \mathrm{ft}$, we considered them to be representative of the surface-temperature distributions. That this is a good approximation can be seen from an inspection. of Table IV of Ref. 7 .

\section{ANALYSIS}

A.ll the plume data identified in Section 4 as useful were accompanied by isotherm plots of the individual plumes. Data reduction, therefore, essentially consisted of planimeter measurements of areas within isotherms for those cases for which the areas were not reported by the field investigators.

The data were displayed on log-log paper with $\theta / \theta_{0}$ plotted against $A / Q^{a}$. 'The most consistent grouping of the buoyant-plume data occurred for $a=1$, that is, on a plot of the form $\theta / \theta_{0}$ versus $A / Q$. Figure 1 shows the data so displayed. (The data key for Fig. 1 is shown in Table II.) The curve drawn through the buoyant-plume data is an eyeball fit to these data. The "sinking"-plume curve may not be representative, since it is based on data from only two plume measurements. 


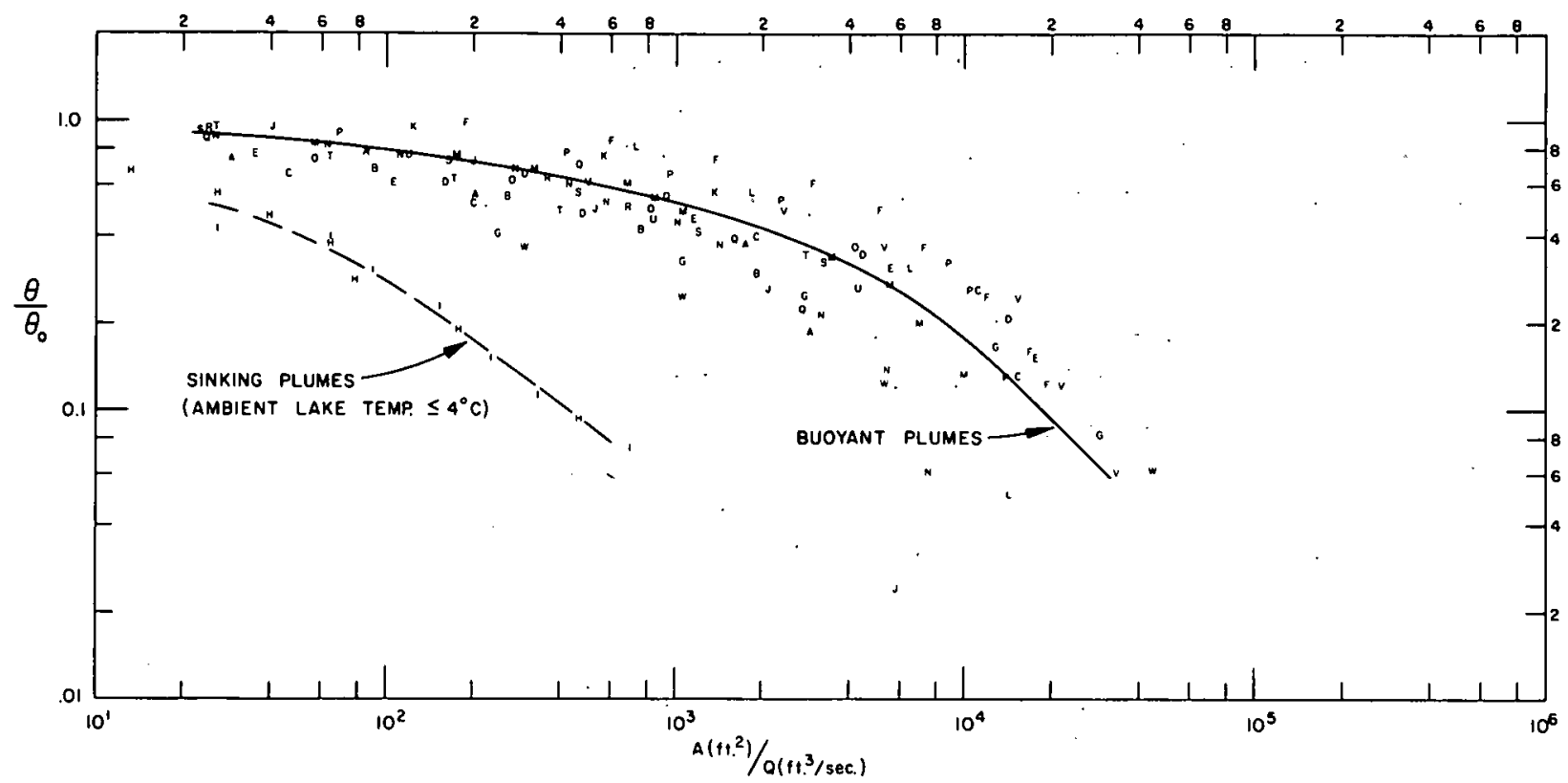

Fig. 1. Fractional Excess Temperature $\left(\frac{\theta}{\theta_{0}}\right)$ vs the Ratio $\frac{\text { Surface Area (A) }}{\text { Discharge Flow Rate (Q) }}$

TABLE II. Data Key for Fig. 1

A. Waukegan ${ }^{2}(7 / 14 / 70,17: 30-13: 37)$
B. Waukegan $(7 / 14 / 70,14: 50-16: 10)$
C. Waukegan $(8 / 12 / 70,12: 00-13: 57)$
D. Waukegan ${ }^{2}(8 / 12 / 70,16: 22-17: 53)$
E. Waukegan ${ }^{2}(8 / 13 / 70,12: 12-13: 26)$
F. Big Rock Point ${ }^{3}(6 / 18 / 68)$
G. Milliken ${ }^{4}(9 / 17 / 68)$
H. Milliken ${ }^{4}(12 / 10 / 68)$
I. Milliken ${ }^{4}(1 / 8 / 69)$
J. Michigan City ${ }^{5}(6 / 26 / 69)$
K. Michigan City ${ }^{5}(6 / 28 / 69)$
L. Waukegan $(6 / 30 / 69)$

M. Allen S. King $^{6}(8 / 20 / 69)$

N. Allen S. King $(9 / 4 / 69)$

O. Allen S. King 6 (7/30/69)

P. Allen S: King $^{6}(6 / 5 / 70)$

Q. Allen S. $\mathrm{King}^{6}(6 / 12 / 70)$

R. Allen S. King $6 / 29 / 70)$

S. Allen S. King 6 (7/9/70)

T. Allen S. $\operatorname{King}^{6}(7 / 17 / 70)$

U. Allen S. King ${ }^{6}(8 / 13 / 70)$

V. Douglas Point ${ }^{7}(8 / 24 / 70)$

W. Douglas Point ${ }^{7}(8 / 25 / 70)$

\section{DISCUSSION}

When considered against the various causes of scatter, the clustering of the buoyant-plume data about the central curve in Fig. 1 is remarkable. Sources of scatter among the data points include:

(1) Large plume-to-plume variation in ambient diffusivity, ambient velocity, and plume depth. Although the magnitude of the scaling area should be strongly dependent upon them, these variables have not been included in the parameterization of $A_{n}$. 
(2) Inaccurate plume areas, especially in the far-field region, where ambient "noise" and plume meandering can produce significant errors in the mapping of thermal plumes. Nearly synoptic, infrared measurements of the type performed by Sundaram et al. should be less susceptible to this type of error.

(3) Different outfall geometries. Although all the outfalls are of the channel type, orifice dimensions and bottom topographies differ considerably. For example; at Waukegan the mouth of the outfall is approximately $6 \mathrm{ft}$ deep by $60 \mathrm{ft}$ wide and the bottom slope is at most $1: 100$, whereas at the Milliken Station the outfall mouth is approximately $10 \mathrm{ft}$ square and the bottom slope is about $1: 10$.

(4) The parameterization $A_{n} \approx Q$ may not be optimum. There may exisl d rnure suitable parameterization, which would lead to a more consistent grouping of the data.

All the data shown on Fig. I refer to channel outfall geometries. Other outfall geometries, such as submerged diffuser systems, could produce temperature decays that are inconsistent with those in Fig. 1. It may turn out, however, that the main difference between channel outfalls and other systems is the point at which the curve shown in Fig. 1 is initially intercepted. Consider, for example, a system that uses rapid, subsurface dilution and produces a maximum surface temperature of, say, $\theta / \theta_{0}=0.7$. Since the initial temperature reduction is achieved simply by dilution, thc initial surface area within the $\theta / A_{0}=0.7$ isotherm may bc consisterit wilh that predicted by Fig. 1. The subsequent temperature decay may also follow the curve in Fig. I.

\section{SUMMARY OF RESULTS}

Figure 1 summarizes the results of the investigation. All the buoyant-plume data are seen to be reasonably well fit by the curve drawn through the data points. The curve thus represents a phenomenological fit relating fractional excess temperature to the quotient of plume surface area and volumetric discharge flow rate.

The plume data shown in Fig. 1 refer to channel outfall geometries. The fit, therefore, may not be applicable to other outfall geometries, particularly in the region where $\theta / \theta_{0}$ is large. Allowing for this restriction, we believe that the curve represents a useful rule of thumb for prcdicting surface areas of buoyant thermal plumes. 


\section{APPENDIX}

\section{Plume Areas}

Power plant: Waukegan

Body of water: Lake Michigan

Investigators: Romberg et al. ${ }^{2}$

Date: $7 / 14 / 70(12: 00-13: 57)$

Discharge flow rate: $Q=1871 \mathrm{ft}^{3} / \mathrm{sec}$

Outfall temperature: $T_{D}=22.3^{\circ} \mathrm{C}$

Ambient temperature: $\mathrm{T}_{\mathrm{A}}=17.0^{\circ} \mathrm{C}$

$\theta_{0}=\mathrm{T}_{\mathrm{D}}-\mathrm{T}_{\mathrm{A}}=5.3^{\circ} \mathrm{C}$

\begin{tabular}{ccc}
\hline $\begin{array}{c}\text { Excess } \\
\text { Temp, } \\
\theta,{ }^{\circ} \mathrm{C}\end{array}$ & $\begin{array}{c}\text { Fractional } \\
\text { Excess } \\
\text { Temp, } \theta / \theta_{0}\end{array}$ & $\begin{array}{c}\text { Total Plume Area, A, } \\
\text { within Isotherm at } \\
\text { Excess Temp, } \mathrm{ft}^{2}\end{array}$ \\
\hline 4.0 & 0.755 & $5.488 \times 10^{4}$ \\
3.0 & 0.566 & $3.841 \times 10^{5}$ \\
2.0 & 0.377 & $3.293 \times 10^{6}$ \\
1.0 & 0.189 & $5.488 \times 10^{6}$ \\
\hline
\end{tabular}

Power plant: Waukegan

Body of water: Lake Michigan

Investigators: Romberg et al. ${ }^{2}$

Date: $8 / 12 / 70(12: 00-13: 57)$

Discharge flow rate: $Q=1730 \mathrm{ft}^{3} / \mathrm{sec}$

Outfall temperature: $\mathrm{T}_{\mathrm{D}}=30.5^{\circ} \mathrm{C}$

Ambient temperature: $\mathrm{T}_{\mathrm{A}}=23.0^{\circ} \mathrm{C}$

$\theta_{0}=\mathrm{TD}_{\mathrm{D}}-\mathrm{T}_{\mathrm{A}}=7.5^{\circ} \mathrm{C}$

\begin{tabular}{ccc}
\hline $\begin{array}{c}\text { Excess } \\
\begin{array}{c}\text { Temp, } \\
\theta,{ }^{\circ} \mathrm{C}\end{array}\end{array}$ & $\begin{array}{c}\text { Fractional } \\
\text { Excess } \\
\text { Temp, } \theta / \theta_{0}\end{array}$ & $\begin{array}{c}\text { Total Plume Area, A, } \\
\text { within Isotherm at } \\
\text { Excess Temp, } \mathrm{ft}^{2}\end{array}$ \\
\hline 5.0 & 0.667 & $8.070 \times 10^{4}$ \\
4.0 & 0.533 & $3.497 \times 10^{5}$ \\
3.0 & 0.400 & $3.309 \times 10^{6}$ \\
2.0 & 0.267 & $1.945 \times 10^{7}$ \\
1.0 & 0.133 & $2.690 \times 10^{7}$ \\
\hline
\end{tabular}

Power plant: Waukegan

Body of water: Lake Michigan Investigators: Romberg et al.$^{2}$ Date: 7/14/70 (14:50-16:10)

Discharge flow rate: $Q=1871 \mathrm{ft}^{3} / \mathrm{sec}$ Outfall temperature: $T_{D}=24.4^{\circ} \mathrm{C}$

Ambient temperature: $\mathrm{T}_{\mathrm{A}}=16.7^{\circ} \mathrm{C}$ $\theta_{0}=T_{D}-T_{A}=7.7^{\circ} \mathrm{C}$

\begin{tabular}{ccc}
\hline $\begin{array}{c}\text { Excess } \\
\begin{array}{c}\text { Temp, } \\
\theta,{ }^{\circ} \mathrm{C}\end{array}\end{array}$ & $\begin{array}{c}\text { Fractional } \\
\text { Excess } \\
\text { Temp, } \theta / \theta_{0}\end{array}$ & $\begin{array}{c}\text { Total Plume Area, A, } \\
\text { within Isotherm at } \\
\text { Excess Temp, } \mathrm{ft}^{2}\end{array}$ \\
\hline 5.3 & 0.688 & $1.722 \times 10^{5}$ \\
4.3 & 0.558 & $4.950 \times 10^{5}$ \\
3.3 & 0.429 & $1.431 \times 10^{6}$ \\
2.3 & 0.299 & $3.615 \times 10^{6}$ \\
\hline
\end{tabular}

Power plant: Waukegan

Body of water: Lake Michigan

Investigators: Romberg et al. ${ }^{2}$

Date: $8 / 12 / 70$ (16:22-17:53)

Discharge flow rate: $Q=1730 \mathrm{ft}^{3} / \mathrm{sec}$

Outfall temperature: $T_{D}=30.6^{\circ} \mathrm{C}$

Ambient temperature: $\mathrm{T}_{\mathrm{A}}=23.5^{\circ} \mathrm{C}$

$\theta_{0}=T_{D}-T_{A}=7.1^{\circ} \mathrm{C}$

\begin{tabular}{ccc}
\hline $\begin{array}{c}\text { Excess } \\
\begin{array}{c}\text { Temp, } \\
\theta,{ }^{\circ} \mathrm{C}\end{array}\end{array}$ & $\begin{array}{c}\text { Fractional } \\
\text { Excess } \\
\text { Temp, } \theta / \theta_{0}\end{array}$ & $\begin{array}{c}\text { Total Plume Area, A, } \\
\text { within Isotherm at } \\
\text { Excess Temp, } \mathrm{ft}^{2}\end{array}$ \\
\hline 4.5 & 0.634 & $2.798 \times 10^{5}$ \\
3.5 & 0.493 & $8.393 \times 10^{5}$ \\
2.5 & 0.352 & $7.833 \times 10^{6}$ \\
1.5 & 0.211 & $2.462 \times 10^{7}$ \\
\hline
\end{tabular}


Power plant: Waukegan

Body of water: Lake Michigan

Investigators: Romberg et al.$^{2}$

Date: $8 / 13 / 70(12: 12-13: 26)$

Discharge flow rate: $Q=1624 \mathrm{ft}^{3} / \mathrm{sec}$

Outfall temperature: $\mathrm{T}_{\mathrm{D}}=29.4^{\circ} \mathrm{C}$

Ambient temperature: $\mathrm{T}_{\mathrm{A}}=23.0^{\circ} \mathrm{C}$

$\theta_{0}=T_{D}-T_{A}=6.4^{\circ} \mathrm{C}$

\begin{tabular}{ccc}
\hline $\begin{array}{c}\text { Excess } \\
\text { Temp, } \\
\theta,{ }^{\circ} \mathrm{C}\end{array}$ & $\begin{array}{c}\text { Fractional } \\
\text { Excess } \\
\text { Temp, } \theta / \theta_{0}\end{array}$ & $\begin{array}{c}\text { Total Plume Area, A, } \\
\text { within Isotherm at } \\
\text { Excess Temp, } \mathrm{ft}^{2}\end{array}$ \\
\hline 5.0 & 0.781 & $5.810 \times 10^{4}$ \\
4.0 & 0.625 & $1.743 \times 10^{5}$ \\
3.0 & 0.469 & $1.917 \times 10^{6}$ \\
2.0 & 0.313 & $9.180 \times 10^{6}$ \\
10 & 0.156 & $2.905 \times 10^{7}$ \\
\hline
\end{tabular}

Pnwer plant: Milliken

Body nf water: Gayuga Lake

Investigators: Sundaram et al ${ }^{4}$

Datc: $9 / 17 / 68$

nischargo flow rate. $Q=254 \mathrm{fr}^{3} / \mathrm{sec}$

Dutfall tcmpiraluse. $T_{D}=31 . \mathrm{U}^{*} \mathrm{C}$

Ambient lemperature: ${ }^{\circ} \Gamma_{A}=19.0^{\circ} \mathrm{C}$

$\theta_{u}=T_{D}-T_{A}=12.0^{\circ} \mathrm{C}$

\begin{tabular}{ccc}
\hline $\begin{array}{c}\text { Excess } \\
\text { Tomp; } \\
0,{ }^{\circ} \mathrm{C}\end{array}$ & $\begin{array}{c}\text { Fractional } \\
\text { Ercess } \\
\text { Iemp, } \forall / \theta_{0}\end{array}$ & $\begin{array}{c}\text { Total Plume Area, A, } \\
\text { Within } 1 \text { sotherm at } \\
\text { Excess temp, } \mathrm{ft}^{2}\end{array}$ \\
\hline 5.0 & 0.417 & $6.2 \times 10^{4}$ \\
4.0 & 0.333 & $2.72 \times 10^{5}$ \\
3.0 & 0.250 & $7.22 \times 10^{5}$ \\
2.0 & 0.167 & $3.292 \times 10^{6}$ \\
1.0 & 0.083 & $7.422 \times 10^{6}$ \\
\hline
\end{tabular}

Power plant: Big Rock Point

Body of water: Lake Michigan

Investigator: $\mathrm{Krezos \textrm {ki } ^ { 3 }}$

Date: 6/18/68

Discharge flow rate: $Q=111.4 \mathrm{ft}^{3} / \mathrm{sec}$

Outfall temperature: $T_{D}=18.0^{\circ} \mathrm{C}$

Ambient temperature: $T_{A}=10.0^{\circ} \mathrm{C}$

$\theta_{0}=\mathrm{T}_{\mathrm{D}}-\mathrm{T}_{\mathrm{A}}=8.0^{\circ} \mathrm{C}$

\begin{tabular}{ccc}
$\begin{array}{c}\text { Excess } \\
\text { Temp, } \\
\theta,{ }^{\circ} \mathrm{C}\end{array}$ & $\begin{array}{c}\text { Fractional } \\
\text { Excess } \\
\text { Temp, } \theta / \theta_{0}\end{array}$ & $\begin{array}{c}\text { Total Plume Area, A, } \\
\text { within Isotherm at } \\
\text { Excess Temp, } \mathrm{ft}^{2}\end{array}$ \\
\hline 8.0 & 1.000 & $2.150 \times 10^{4}$ \\
7.0 & 0.875 & $6.780 \times 10^{4}$ \\
6.0 & 0.750 & $1.552 \times 10^{5}$ \\
5.0 & 0.625 & $3.398 \times 10^{5}$ \\
4.0 & 0.500 & $5.707 \times 10^{5}$ \\
3.0 & 0.375 & $8.153 \times 10^{5}$ \\
2.0 & 0.250 & $1.347 \times 10^{6}$ \\
1.3 & 0.163 & $1.901 \times 10^{6}$ \\
1.0 & 0.125 & $2.181 \times 10^{6}$ \\
\hline
\end{tabular}

Power plant: Milliken

Body of water: Cayuga Lake

Investigators: Sundaram et al ${ }^{4}$

Date: $12 / 10 / 68$

Discharge flow rate: $Q=377 \mathrm{ft}^{3} /$ ser.

Outfall lemperature: $I_{D}=14.5^{\circ} \mathrm{C}$

Ambient temperature: $\mathrm{T}_{\mathrm{A}}=4.0^{\circ} \mathrm{C}$

$\theta_{0}=\mathrm{T}_{\mathrm{D}}-\mathrm{T}_{\mathrm{A}}=10.5^{\circ} \mathrm{C}$

\begin{tabular}{ccc}
\hline $\begin{array}{c}\text { Excess } \\
\text { Temp, } \\
\theta,{ }^{\circ} \mathrm{C}\end{array}$ & $\begin{array}{c}\text { Fractional } \\
\text { Excess } \\
\text { Temp, } \theta / \theta_{U}\end{array}$ & $\begin{array}{c}\text { Total Plump Area, A, } \\
\text { within Ioothcrm at } \\
\text { Excess Temp, } \mathrm{ft}^{2}\end{array}$ \\
\hline 7.0 & 0.667 & $4.923 \times 10^{3}$ \\
6.0 & 0.571 & $0.846 \times 10^{3}$ \\
5.0 & 0.476 & $1.47 \% \times 10^{4}$ \\
4.0 & 0.381 & $2.462 \times 10^{4}$ \\
3.0 & 0.286 & $2.954 \times 10^{4}$ \\
2.0 & 0.190 & $6.892 \times 10^{4}$ \\
1.0 & 0.095 & $1.772 \times 10^{5}$ \\
\hline
\end{tabular}


Power plant: Milliken

Body of water: Cayuga Lake Investigators: Sundaram et al. ${ }^{4}$ Date: $1 / 8 / 69$

Discharge flow rate: $Q=377 \mathrm{ft}^{3} / \mathrm{sec}$ Outfall temperature: $T_{D}=15.5^{\circ} \mathrm{C}$ Ambient temperature: $\mathrm{T}_{\mathrm{A}}=2.5^{\circ} \mathrm{C}$ $\theta_{0}=\mathrm{T}_{\mathrm{D}}-\mathrm{T}_{\mathrm{A}}=13.0^{\circ} \mathrm{C}$

\begin{tabular}{ccc}
\hline $\begin{array}{c}\text { Excess } \\
\text { Temp, } \\
\theta,{ }^{\circ} \mathrm{C}\end{array}$ & $\begin{array}{c}\text { Eractional } \\
\text { Excess } \\
\text { Temp, } \theta / \theta_{0}\end{array}$ & $\begin{array}{c}\text { Total Plume Area, A, } \\
\text { within Isotherm at } \\
\text { Excess Temp, } \mathrm{ft}^{2}\end{array}$ \\
\hline 5.5 & 0.423 & $9.846 \times 10^{3}$ \\
5.0 & 0.385 & $2.462 \times 10^{4}$ \\
4.0 & 0.308 & $3.446 \times 10^{4}$ \\
3.0 & 0.231 & $5.908 \times 10^{4}$ \\
2.0 & 0.154 & $8.862 \times 10^{4}$ \\
1.5 & 0.115 & $1.280 \times 10^{5}$ \\
1.0 & 0.077 & $2.658 \times 10^{5}$ \\
\hline
\end{tabular}

Power plant: Michigan City Body of water: Lake Michigan Investigators: Ayers et al ${ }^{5}$ Date: $6 / 28 / 69$

Discharge flow rate: $Q=178 \mathrm{ft}^{3} / \mathrm{sec}$ Outfall temperature: $T_{D}=25.2^{\circ} \mathrm{C}$ Ambient temperature: $\mathrm{T}_{\mathrm{A}}=20.0^{\circ} \mathrm{C}$ $\theta_{0}=\mathrm{T}_{\mathrm{D}}-\mathrm{T}_{\mathrm{A}}=5.2^{\circ} \mathrm{C}$

\begin{tabular}{ccc}
\hline $\begin{array}{c}\text { Excess } \\
\text { Temp, } \\
\theta,{ }^{\circ} \mathrm{C}\end{array}$ & $\begin{array}{c}\text { Fractional } \\
\text { Excess } \\
\text { Temp, } \theta / \theta_{0}\end{array}$ & $\begin{array}{c}\text { Total Plume Area, A, } \\
\text { within Isotherm at } \\
\text { Excess Temp, } \mathrm{ft}^{2}\end{array}$ \\
\hline 5.0 & 0.961 & $2.222 \times 10^{4}$ \\
4.0 & 0.769 & $1.000 \times 10^{5}$ \\
3.0 & 0.576 & $2.444 \times 10^{5}$ \\
\hline
\end{tabular}

Power plant: Michigan City

Body of water: Lake Michigan

Investigators: Ayers et al.

Date: 6/26/69

Discharge flow rate: $Q=537 \mathrm{ft}^{3} / \mathrm{sec}$

Outfall temperature: $T_{D}=21.1^{\circ} \mathrm{C}$

Ambient temperature: $\mathrm{T}_{\mathrm{A}}=16.9^{\circ} \mathrm{C}$

$\theta_{0}=\mathrm{T}_{\mathrm{D}}-\mathrm{T}_{\mathrm{A}}=4.2^{\circ} \mathrm{C}$

\begin{tabular}{ccc}
$\begin{array}{c}\text { Excess } \\
\begin{array}{c}\text { Temp, } \\
\theta,{ }^{\circ} \mathrm{C}\end{array}\end{array}$ & $\begin{array}{c}\text { Fractional } \\
\text { Excess } \\
\text { Temp, } \theta / \theta_{0}\end{array}$ & $\begin{array}{c}\text { Total Plume Area, A, } \\
\text { within Isotherm at } \\
\text { Excess Temp, } \mathrm{ft}^{2}\end{array}$ \\
\hline 4.1 & 0.976 & $2.222 \times 10^{4}$ \\
3.1 & 0.738 & $1.111 \times 10^{5}$ \\
2.1 & 0.500 & $2.889 \times 10^{5}$ \\
1.1 & 0.262 & $1.133 \times 10^{6}$ \\
0.1 & 0.024 & $3.133 \times 10^{6}$ \\
\hline
\end{tabular}

Power plant: Waukegan

Body of water: Lake Michigan

Investigators: Ayers et al ${ }^{5}$

Date: 6/30/69

Discharge flow rate: $Q=1872 \mathrm{ft}^{3} / \mathrm{sec}$

Outfall temperature: $T_{D}=16.6^{\circ} \mathrm{C}$

Ambient temperature: $\mathrm{T}_{\mathrm{A}}=12.8^{\circ} \mathrm{C}$ $\theta_{0}=\mathrm{T}_{\mathrm{D}}-\mathrm{T}_{\mathrm{A}}=3.8^{\circ} \mathrm{C}$

\begin{tabular}{ccc}
\hline $\begin{array}{c}\text { Excess } \\
\begin{array}{c}\text { Temp, } \\
\theta,{ }^{\circ} \mathrm{C}\end{array}\end{array}$ & $\begin{array}{c}\text { Fractional } \\
\text { Excess } \\
\text { Temp, } \theta / \theta_{0}\end{array}$ & $\begin{array}{c}\text { Total Plume Area, A, } \\
\text { within Isotherm at } \\
\text { Excess Temp, } \mathrm{ft}^{2}\end{array}$ \\
\hline 3.2 & 0.842 & $1.39 \times 10^{6}$ \\
2.2 & 0.579 & $3.48 \times 10^{6}$ \\
1.2 & 0.316 & $1.219 \times 10^{7}$ \\
0.2 & 0.052 & $2.700 \times 10^{7}$ \\
\hline
\end{tabular}


Power plant: Allen S. King

Body of water: Lake St. Croix

Investigator: $\mathrm{Fitch}^{6}$

Date: $8 / 20 / 69$

Discharge flow rate: $Q=660 \mathrm{ft}^{3} / \mathrm{sec}$

Outfall temperature: $T_{D}=93.25^{\circ} \mathrm{F}$

Ambient temperature: $T_{A}=79.1^{\circ} \mathrm{F}$

$\theta_{0}=T_{D}-T_{A}=14.15^{\circ} \mathrm{F}$

\begin{tabular}{ccc}
\hline $\begin{array}{c}\text { Excess } \\
\text { Temp, } \\
,^{\circ}{ }^{\circ} \mathrm{F}\end{array}$ & $\begin{array}{c}\text { Fractional } \\
\text { Excess } \\
\text { Temp, } \theta / \theta_{0}\end{array}$ & $\begin{array}{c}\text { Total Plume Area, A, } \\
\text { within Isotherm at } \\
\text { Excess Temp, } \mathrm{ft}^{2}\end{array}$ \\
\hline 11.9 & 0.841 & $3.824 \times 10^{4}$ \\
10.9 & 0.770 & $1.166 \times 10^{5}$ \\
9.9 & 0.700 & $2.144 \times 10^{5}$ \\
8.9 & 0.679 & $1.545 \times 10^{5}$ \\
7.9 & 0.558 & $5.624 \times 10^{5}$ \\
6.9 & 0.488 & $7.041 \times 10^{5}$ \\
4.9 & 0.346 & $2.339 \times 10^{6}$ \\
3.9 & 0.276 & $3.669 \times 10^{6}$ \\
2.9 & 0.205 & $4.729 \times 10^{6}$ \\
1.9 & 0.134 & $6.708 \times 10^{6}$ \\
\hline
\end{tabular}

Powor plant: Allen S. King

Body of water: Lake St. Crulx

Investigitinr: $\Gamma$ it $\mathrm{l}^{6}$

Datc: $7 / 30 / 69$

Dischargc flow rate: $Q=660 \mathrm{ft}^{3} / \mathrm{sec}$

Outfall temperature: $\mathrm{T}_{\mathrm{D}}=86.0^{\circ} \mathrm{F}$

Ambient temperature: $\mathrm{T}_{\mathrm{A}}=78.0^{\circ} \mathrm{F}$

$\theta_{U}=T_{U}-T_{A}-8^{n} \mathbf{F}$

\begin{tabular}{ccc}
$\begin{array}{c}\text { Excess } \\
\text { Temp, } \\
\theta,{ }^{\circ} \mathrm{F}\end{array}$ & $\begin{array}{c}\text { Fractional } \\
\text { Excess } \\
\text { Temp, } \theta / \theta_{0}\end{array}$ & $\begin{array}{c}\text { Total Plume Area, A, } \\
\text { within Isotherm at } \\
\text { Excess Temp, } \mathrm{ft}^{2}\end{array}$ \\
\hline 6.0 & 0.750 & $3.715 \times 10^{4}$ \\
5.0 & 0.625 & $1.825 \times 10^{5}$ \\
4.0 & 0.500 & $5.500 \times 10^{5}$ \\
3.0 & 0.375 & $2.784 \times 10^{6}$
\end{tabular}

Power plant: Allen S. King

Body of water: Lake St. Croix

Investigator: $\mathrm{Fitch}^{6}$

Date: $9 / 4 / 69$

Discharge flow rate: $Q=660 \mathrm{ft}^{3} / \mathrm{sec}$

Outfall temperature: $T_{D}=91.13^{\circ} \mathrm{F}$

Ambient temperature: $\mathrm{T}_{\mathrm{A}}=78.2^{\circ} \mathrm{F}$

$\theta_{0}=T_{D}-T_{A}=12.93^{\circ} \mathrm{F}$

\begin{tabular}{ccc}
\hline $\begin{array}{c}\text { Excess } \\
\text { Temp, } \\
,^{\circ} \mathrm{F}\end{array}$ & $\begin{array}{c}\text { Fractional } \\
\text { Excess } \\
\text { Temp, } \theta / \theta_{0}\end{array}$ & $\begin{array}{c}\text { Total Plume Area, A, } \\
\text { within Isotheriat } \\
\text { Excess Temp, } \mathrm{ft}^{2}\end{array}$ \\
\hline 11.8 & 0.913 & $1.708 \times 10^{4}$ \\
10.8 & 0.835 & $4.175 \times 10^{4}$ \\
9.8 & 0.758 & $7.400 \times 10^{4}$ \\
8.6 & 0681 & $1.853 \times 10^{5}$ \\
7.8 & $0.6 \cup 3$ & $2.821 \times 10^{5}$ \\
6.8 & 0.526 & $3.814 \times 10^{5}$ \\
5.8 & 0.449 & $6.641 \times 10^{5}$ \\
4.8 & 0.371 & $9.437 \times 10^{5}$ \\
2.8 & 0.217 & $2.108 \times 10^{6}$ \\
1.8 & 0.139 & $3.574 \times 10^{6}$ \\
0.8 & 0.062 & $4.948 \times 10^{6}$ \\
\hline
\end{tabular}

Power plant: Allen S. King

Body of water: Lake St. Croix Investigator: Fitch $^{6}$

Date: $6 / 5 / 70$

Discharge flow rate: $Q=457 \mathrm{ft}^{3} / \mathrm{sec}$

Outfall temperature: $\mathrm{T}_{\mathrm{D}}=85.25^{\circ} \mathrm{F}$

Ambient temperature. $\mathrm{T}_{\mathrm{A}}-70.0^{\circ} \mathrm{F}$

$\theta_{0}=T_{D}-T_{A}=15.25^{\circ} \mathrm{F}$

\begin{tabular}{ccc}
$\begin{array}{c}\text { Excess } \\
\text { Temp, } \\
{ }^{\circ}{ }^{\circ} \mathrm{F}\end{array}$ & $\begin{array}{c}\text { Fractional } \\
\text { Excess } \\
\text { Temp, } \theta / \theta_{0}\end{array}$ & $\begin{array}{c}\text { Total Plume Area, A, } \\
\text { within Isotherm at } \\
\text { Excess Tempi. } \mathrm{ft}^{2}\end{array}$ \\
\hline 14.0 & 0.918 & $3.150 \times 10^{4}$ \\
12.0 & 0.787 & $1.969 \times 10^{5}$ \\
10.0 & 0.656 & $4.331 \times 10^{5}$ \\
8.0 & 0.525 & $1.063 \times 10^{6}$ \\
5.0 & 0.328 & $4.071 \times 10^{6}$ \\
4.0 & 0.262 & $4.995 \times 10^{6}$ \\
2.0 & 0.131 & $6.433 \times 10^{6}$ \\
\hline
\end{tabular}


Power plant: Allen S. King

Body of water: Lake St. Croix

Investigator: $\mathrm{Fitch}^{6}$

Date: $6 / 12 / 70$

Discharge flow rate: $Q=638.6 \mathrm{ft}^{3} / \mathrm{sec}$

Outfall temperature: $\mathrm{T}_{\mathrm{D}}=91.35^{\circ} \mathrm{F}$

Ambient temperature: $\mathrm{T}_{\mathrm{A}}=79.2^{\circ} \mathrm{F}$

$\theta_{0}=T_{D}-T_{A}=12.15^{\circ} \mathrm{F}$

\begin{tabular}{ccc}
$\begin{array}{c}\text { Excess } \\
\begin{array}{c}\text { Temp, } \\
\theta,{ }^{\circ} \mathrm{F}\end{array}\end{array}$ & $\begin{array}{c}\text { Eractional } \\
\text { Excess } \\
\text { Temp, } \theta / \theta_{0}\end{array}$ & $\begin{array}{c}\text { Total Plume Area, A; } \\
\text { within Isotherm at } \\
\text { Excess Temp, ft }\end{array}$ \\
\hline 10.8 & 0.889 & $1.550 \times 10^{4}$ \\
8.8 & 0.724 & $2.946 \times 10^{5}$ \\
6.8 & 0.560 & $5.969 \times 10^{5}$ \\
4.8 & 0.395 & $1.047 \times 10^{6}$ \\
2.8 & 0.230 & $1.791 \times 10^{6}$ \\
\hline
\end{tabular}

Power plant: Allen S. King

Body of water: Lake St. Croix

Investigator: $\mathrm{Fitch}^{6}$

Date: $7 / 9 / 70$

Discharge flow rate: $Q=614.8 \mathrm{ft}^{3} / \mathrm{sec}$

Outfall temperature: $\mathrm{T}_{\mathrm{D}}=93.1^{\circ} \mathrm{F}$

Ambient temperature: $\mathrm{T}_{\mathrm{A}}=80.9^{\circ} \mathrm{F}$

$\theta_{0}=T_{D}-T_{A}=12.2^{\circ} \mathrm{F}$

\begin{tabular}{ccc}
\hline $\begin{array}{c}\text { Excess } \\
\begin{array}{c}\text { Temp, } \\
\theta,{ }^{\circ} \mathrm{F}\end{array}\end{array}$ & $\begin{array}{c}\text { Fractional } \\
\text { Excess } \\
\text { Temp, } \theta / \theta_{0}\end{array}$ & $\begin{array}{c}\text { Total Plume Area, A, } \\
\text { within Isotherm at } \\
\text { Excess 'lemp, } \mathrm{ft}^{7}\end{array}$ \\
\hline 11.1 & 0.910 & $1.504 \times 10^{4}$ \\
9.1 & 0.746 & $1.053 \times 10^{5}$ \\
7.1 & 0.582 & $2.857 \times 10^{5}$ \\
5.1 & 0.418 & $7.444 \times 10^{5}$ \\
4.1 & 0.336 & $2.090 \times 10^{6}$ \\
\hline
\end{tabular}

Power plant: Allen S. King

Body of water: Lake St. Croix Investigator: Fitch ${ }^{6}$

Date: $6 / 29 / 70$

Discharge flow rate: $Q=627.1 \mathrm{ft}^{3} / \mathrm{sec}$

Outfall temperature: $\mathrm{T}_{\mathrm{D}}=93.0^{\circ} \mathrm{F}$

Ambient temperature: $\mathrm{T}_{\mathrm{A}}=78.8^{\circ} \mathrm{F}$

$\theta_{0}=T_{D}-T_{A}=14.2^{\circ} \mathrm{F}$

\begin{tabular}{ccc}
\hline $\begin{array}{c}\text { Excess } \\
\text { Temp, } \\
\theta,{ }^{\circ} \mathrm{F}\end{array}$ & $\begin{array}{c}\text { Fractional } \\
\text { Excess } \\
\text { Temp, } \theta / \theta_{0}\end{array}$ & $\begin{array}{c}\text { Total Plume Area, A, } \\
\text { within Isotherm at } \\
\text { Excess Temp, } \mathrm{ft}^{2}\end{array}$ \\
\hline 13.2 & 0.930 & $1.563 \times 10^{4}$ \\
11.2 & 0.789 & $5.469 \times 10^{4}$ \\
9.2 & 0.648 & $2.266 \times 10^{5}$ \\
7.2 & 0.507 & $4.375 \times 10^{5}$ \\
\hline
\end{tabular}

Power plant: Allen S. King

Body of water: Lake St. Croix

Investigator: $\mathrm{Fitch}^{6}$

Date: $7 / 17 / 70$

Discharge flow rate: $Q=591.1 \mathrm{ft}^{3} / \mathrm{sec}$

Outfall temperature: $T_{D}=95.13^{\circ} \mathrm{F}$

Ambient temperature: $\mathrm{T}_{\mathrm{A}}=81.1^{\circ} \mathrm{F}$

$\theta_{0}=T_{D}-T_{A}=14.03^{\circ} \mathrm{F}$

\begin{tabular}{ccc}
\hline $\begin{array}{c}\text { Excess } \\
\text { Temp, } \\
0,{ }^{\circ} \mathrm{T}\end{array}$ & $\begin{array}{c}\text { Eractional } \\
\text { Excess } \\
\text { Tomp, } 9 / \mathrm{A}_{0}\end{array}$ & $\begin{array}{c}\text { Total Plume Area, A, } \\
\text { within Isotherm at } \\
\text { Excess Temp, } \mathrm{ft}^{2}\end{array}$ \\
\hline 12.9 & 0.919 & $1.538 \times 10^{4}$ \\
10.9 & 0.777 & $3.846 \times 10^{4}$ \\
8.9 & 0.634 & $1.000 \times 10^{5}$ \\
6.9 & 0.492 & $2.462 \times 10^{5}$ \\
$4 . \dot{9}$ & 0.349 & $1.700 \times 10^{6}$ \\
\hline
\end{tabular}


Power plant: Allen S. King

Body of water: Lake St. Croix

Investigator: Fitch $^{6}$

Date: $8 / 13 / 70$

Discharge flow rate: $Q=623.7 \mathrm{ft}^{3} / \mathrm{sec}$

Outfall temperature: $T_{D}=91.25^{\circ} \mathrm{F}$

Ambient temperature: $\mathrm{T}_{\mathrm{A}}=81.3^{\circ} \mathrm{F}$

$\theta_{0}=T_{D}-T_{A}=9.95^{\circ} \mathrm{F}$

\begin{tabular}{ccc}
\hline $\begin{array}{c}\text { Excess } \\
\text { Temp, } \\
\theta,{ }^{\circ} \mathrm{F}\end{array}$ & $\begin{array}{c}\text { Eractional } \\
\text { Excess } \\
\text { Temp, } \theta / \theta_{0}\end{array}$ & $\begin{array}{c}\text { Total Plume Area, A, } \\
\text { within Isotherm at } \\
\text { Excess Temp, } \mathrm{ft}^{2}\end{array}$ \\
\hline 7.7 & 0.774 & $7.576 \times 10^{4}$ \\
6.7 & 0.673 & $1.894 \times 10^{5}$ \\
4.7 & 0.472 & $5.152 \times 10^{5}$ \\
2.7 & 0.271 & $2.598 \times 10^{6}$ \\
\hline
\end{tabular}

Power plant: Douglas Point

Body of water: Lake Huron

Investigators: Csanady et al. ${ }^{7}$

Date: $8 / 24 / 70$

Discharge flow rate: $Q=397 \mathrm{ft}^{3} / \mathrm{sec}$

Outfall temperature: $T_{D}=28.3^{\circ} \mathrm{C}$

Ambient temperature: $\mathrm{T}_{\mathrm{A}}=20.3^{\circ} \mathrm{C}$

$\theta_{0}=T_{D}-T_{A}=8.0^{\circ} \mathrm{C}$

\begin{tabular}{ccc}
\hline $\begin{array}{c}\text { Excess } \\
\text { Temp, } \\
\theta,{ }^{\circ} \mathrm{C}\end{array}$ & $\begin{array}{c}\text { Fractional } \\
\text { Excess } \\
\text { Temp. } \theta / \theta_{0}\end{array}$ & $\begin{array}{c}\text { Total Plume Area, A, } \\
\text { within Isotherm at } \\
\text { Excess Temp, } \mathrm{ft}^{2}\end{array}$ \\
\hline 5.0 & 0.625 & $2.013 \times 10^{5}$ \\
1.0 & 0.500 & $9.515 \times 10^{9}$ \\
3.0 & 0.375 & $2.123 \times 10^{6}$ \\
2.0 & 0.250 & $6.130 \times 10^{6}$ \\
1.0 & 0.125 & $8.637 \times 10^{6}$ \\
0.5 & 0.1163 & $1.350 \times 10^{7}$ \\
\hline
\end{tabular}

Power planti Mnuglas Point

Body of water: Take Huron

Investigators: Csanady et al. ${ }^{7}$

Date: $8, / 25 / 70$

Discharge, flow rate: $Q=397 \mathrm{ft}^{3} / \mathrm{sec}$

Qutfall temporature: $T_{D} \cdot 28.1^{\circ} \mathrm{C}$

Ambicnt temperature, $\mathrm{T}_{\mathrm{A}}=20.1^{\circ} \mathrm{C}$

$\theta_{0}=\mathrm{T}_{\mathrm{D}}-\mathrm{T}_{\mathrm{A}}=8.0^{\circ} \mathrm{C}$

\begin{tabular}{ccc}
\hline $\begin{array}{c}\text { Excess } \\
\text { Temp, } \\
,^{\circ} \mathrm{C}\end{array}$ & $\begin{array}{c}\text { Fractional } \\
\text { Excess } \\
\text { Ternp, } \theta / \theta_{0}\end{array}$ & $\begin{array}{c}\text { Total Plumc Area, A, } \\
\text { within Isotherm at } \\
\text { Excess Temp, } \mathrm{ft}^{2}\end{array}$ \\
\hline 3.0 & 0.375 & $1.200 \times 10^{5}$ \\
2.0 & 0.250 & $4.200 \times 10^{5}$ \\
1.0 & 0.125 & $2.060 \times 10^{6}$ \\
0.5 & 0.063 & $1.824 \times 10^{7}$ \\
\hline
\end{tabular}




\section{ACKNOWLEDGMENTS}

We should like to thank B. M. Hoglund and A. J. Policastro for useful comments and discussions, and to especially thank J. V. Tokar for making available to us several sets of plume data he had acquired from other investigators. 


\section{REFERENCES}

1. J. R. Edinger and E. M. Polk, Initial Mixing of Thermal Discharges into a Uniform Current, Report No. 1, Department of Environmental and Water Resources Engineering, Vanderbilt University (Oct 1969).

2. G. P. Romberg, W. Prepejchal, and D. M. Nelson, "Thermal Plume Measurements," to be published in Proceedings of the 14th Conference on Great Lakes Research, 1971, by the International Association for Great Lakes Research.

3. J. R. Krezoski, Some Effects of Power Plant Waste Heat Discharge on the Ecology of Lake Michigan, Benton Harbor Power Plant Limnological Studies, Part III, Special Report No. 44 of the Great Lakes Research Division, The University of Michigan, Ann Arbor, Michigan (Apr 1969).

4. T. R. Sundaram, C. C. Fastarbrook, K, R. Piech, and G. Kudinger, An Investigation of the Physical Effects of Thermal Discharges into Cayuga Lake (Anulylicul study), CAL Report No. VT-2616-0-2 (Nov 1969).

5. J. C. Ayers, R. F. Anderson, N. W. O'Hara, and C. C. Kidd, Cook Plant Preoperational Studies, 1969, Benton Harbor Power Plant Limnological Studies, Part IV, Special Report No. 44 of the Great Lakes Research Division, The University of Michigan, Ann Arbor, Michigan (Mar 1970).

6. N. R. Fitch, Temperature Surveys of St. Croix River, 1909-1970, for the AZZen S. King Generating Plant, Oak Park Heights, Minnesota, Northern States Power Company Environmental Monitoring Program Report (Dec 31, 1970).

7. 'I. 'I. Csanady, W. R. Crawford, and B. Pade, Thermal Plume Study at Douglas Point, Lake Huron, 1970. 